\title{
Bardet-Biedl syndrome proteins control cilia length through regulation of actin polymerisation
}

\author{
V Hernandez ${ }^{1 *}$, P Pravincumar ${ }^{2}$, A Diaz-Font ${ }^{1}$, H May-Simera ${ }^{3}$, D Jenkins ${ }^{1}$, M Knight $^{2}$, PL Beales ${ }^{1}$ \\ From First International Cilia in Development and Disease Scientific Conference (2012) \\ London, UK. 16-18 May 2012
}

Primary cilia are cellular appendages important for signal transduction and sensing the environment. Bardet-Biedl syndrome proteins form a complex that is important for several cytoskeleton-related processes such as ciliogenesis, cell migration and division. However, the mechanism by which BBS proteins may regulate the cytoskeleton remain unclear. We discovered that Bbs4 and Bbs6 deficient renal medullary cells display a characteristic behaviour comprising poor migration, adhesion and division with an inability to form lamellipodial and filopodial extensions. Moreover, few cells were ciliated $(48 \% \pm 6$ for WT cells vs $23 \% \pm 7$ for Bbs4 null cells) and bear shorter cilia $(2.55 \mu \mathrm{m} \pm 0.41$ for WT cells vs $2.16 \mu \mathrm{m} \pm 0.23$ for Bbs 4 null cells). Whilst the microtubular cytoskeleton and cortical actin was intact, the actin cytoskeleton was severely disrupted, forming abnormal apical stress fiber aggregates. Furthermore, we observed over-abundant focal adhesions in Bbs4, Bbs6 and $B b s 8$-deficient cells. In view of these findings and the role of RhoA in regulation of actin filament polymerisation, we showed that RhoA-GTP (activated form) levels were highly upregulated in the absence of Bbs proteins. Upon treatment of Bbs4-deficient cells with a RhoA inhibitor, Y27632, we were able to restore cilia length and number as well as the integrity of the actin cytoskeleton. Together these findings indicate that Bbs proteins play a central role in the regulation of the actin cytoskeleton and control cilia length through alteration of RhoA levels.

\section{Author details}

${ }^{1}$ Molecular Medicine Unit, UCL Institute of Child Health London, UK. ${ }^{2}$ School of Engineering and Materials Science, Queen Mary University of London, London, UK. ${ }^{3}$ National Institute of Deafness and Communication Disorders, NIH, Bethesda, MD, USA.

Published: 16 November 2012

* Correspondence: v.hernandez@ucl.ac.uk

${ }^{1}$ Molecular Medicine Unit, UCL Institute of Child Health London, UK

Full list of author information is available at the end of the article
doi:10.1186/2046-2530-1-S1-P88

Cite this article as: Hernandez et al: Bardet-Biedl syndrome proteins control cilia length through regulation of actin polymerisation. Cilia 2012 1(Suppl 1):P88.
Submit your next manuscript to BioMed Central and take full advantage of:

- Convenient online submission

- Thorough peer review

- No space constraints or color figure charges

- Immediate publication on acceptance

- Inclusion in PubMed, CAS, Scopus and Google Scholar

- Research which is freely available for redistribution

Submit your manuscript at www.biomedcentral.com/submit

\section{() Biomed Central}

C Biomed Central

(c) 2012 Hernandez et al; licensee BioMed Central Ltd. This is an Open Access article distributed under the terms of the Creative Commons Attribution License (http://creativecommons.org/licenses/by/2.0), which permits unrestricted use, distribution, and reproduction in any medium, provided the original work is properly cited. 